\title{
THE DYNAMICS OF CRYSTAL LATTICE OF SOLID SOLUTIONS BASED ON ZIRCONIUM DIOXIDE
}

\author{
V. I. Slisenko ${ }^{1}$, O. E. Zoteev ${ }^{2}$ (D), O. A. Vasylkevych ${ }^{1}$ (D), V. O. Zoteev ${ }^{2}$ (D), V. V. Krotenko ${ }^{1}$ \\ ${ }^{1}$ Institute for Nuclear Research NASU, 47, Nauky Ave., Kyiv, UA-03028, Ukraine, \\ ${ }^{2}$ Odessa National Polytechnic University, 1, Shevchenko Ave., Odesa, UA-65044, Ukraine \\ e-mail:slisenko@kinr.kiev.ua; a.vas@i.ua; zoteevoleg@i.ua; szoteev@gmail.com
}

(Received 04 February 2021; in final form 09 July 2021; accepted 05 October 2021; published online 03 December 2021)

The paper studies structure and dynamics of the crystal lattice of solid solutions based on zirconium dioxide. Structural experiments were performed on a KSN-2 neutron spectrometer (in the "diffractrometer" mode) and DRON-3.0 X-ray diffractrometer. The phonon spectrum of solid solutions was obtained using the method of inelastic scattering of thermal neutrons. Dispersion ratios were obtained with KSN-2 (in a "triple-axes-spectrometer" mode) on monocrystal samples. It is known that the introduction of such ions as $\mathrm{Ca}, \mathrm{Y}, \mathrm{Nd}$, Sc into the $\mathrm{ZrO}_{2}$ crystal lattice stabilizes the cubic structure of the lattice. Particular attention was paid to the $\mathrm{ZrO}_{2}$ system $-33 \%$ mol. $\mathrm{Y}_{2} \mathrm{O}_{3}$. In this system, the possibility of formation of a pyrochlor structure was considered. It has been suggested that a phase transition occurs in $\mathrm{ZrO}_{2}$-based solid solutions under the influence of neutron irradiation and temperature, which can lead to disruption of coatings made of these materials.

Key words: crystal lattice dynamics, inelastic scattering, thermal neutrons.

DOI: https://doi.org/10.30970/jps.25.4601

\section{INTRODUCTION}

Solid solutions based on zirconium dioxide draw big attention due to their unique physical properties [1]. Zirconium dioxide is a material with a monoclinic structure, but under the influence of pressure, temperature and radiation, the transition to a tetragonal type of lattice can happen, which is accompanied with a change in the specific volume almost on by $10 \ldots 13 \%$ [2]. It is well known that zirconium dioxide layer is formed on the surface of a fuel rod shell during the exploitation of fuel assembly. Particularly the reduction in the specific volume is one of the reasons why that film on the surface of a fuel rod shell may undergo cracking. The destruction of this shell leads to the ingress of radioactive isotopes into the primary circuit coolant of the reactor, which can cause its shutdown. At the same time, it is known that an addition of the rare earth element oxides, in the amount of more than $6 \%$ mole, into the $\left(\mathrm{ZrO}_{2}\right)$ leads to the stabilization of the cubic type of the lattice, which is not changing under the influence of neutron irradiation [3]. In addition, it is known that the speed of the film increment changes with time. The purpose of this work was to investigate of the structure and the lattice dynamics of solid solutions based on zirconium dioxide with the different ion-stabilizer. Knowing the features of the structure and the crystal lattice dynamics of these systems will allow us to create protective coatings for the power equipment of nuclear power plants. Moreover, the development of a technology for applying protective coatings from these materials will make it possible to create protective coatings for a new fuel rod shell based on $\mathrm{SiC}$.

\section{EXPERIMENTAL METHODS}

Structural experiments have been carried out using the neutron spectrometer $\operatorname{KSN}-2(\lambda=0.104 \mathrm{~nm})$ in the "diffractrometer" mode, and X-ray difractrometer DRON-3.0 (in Fe $K \alpha$ radiation $\lambda=0.194 \mathrm{~nm}$ ). Spectra of inelastic scattered slow neutrons were obtained on using the multidetector neutron spectrometer, and the "time-of-fight" method, located on the first horizontal channel of the WWR reactor - of the Institute for the Nuclear Research of National Academy of Sciences of Ukraine using the method described in [4]. The energy of the neutrons' dropping on the sample was $26 \mathrm{meV}$. The polycrystalline samples received using a standard method of hydroxide co-precipitation were studied during these experiments. All samples were subjected to the standard annealing during $7.2 \times 10^{5} \mathrm{sec}$ at $720 \mathrm{~K}$. The size of particles was determined the BS-613 microscope. Dispersion ratios were obtained using KSN-2 (in a "triple-axes-spectrometer" mode) on monocrystalline samples.

\section{RESULTS OF EXPERIMENTS AND THEIR ANALYSIS}

During the study of solid solutions based on $\mathrm{ZrO}_{2}$, the greatest attention was paid to the $\mathrm{ZrO}_{2}-\mathrm{Y}_{2} \mathrm{O}_{3}$ system, which is used quite often for practical purposes [5]. The data from the neutronographic measurement has shown that an introduction of about $6 \%$ mol. of yttrium oxide to the crystal lattice of zirconium dioxide stabilizes its cubic structure. The X-ray structural analysis of these solid solutions has confirmed the results of the neutrongraphic 
measurement. The study of the crystal lattice dynamics was done in a non-coherent approximation.

In studies of complex crystals in which there are several different atoms in the unit cell, it is not possible to obtain the density of normal oscillations $g(\varepsilon)$ directly without the involvement of model calculations. In this case, the so-called average weighted density of phonon states $G(\varepsilon)$ is determined.

It is equal to $g(\varepsilon)$ multiplied by some function $H_{s}(k, \varepsilon)$, which depends on the amplitudes of coherent scattering, masses and polarization vectors of the modes of individual atoms in the unit cell. The connection between the double differential cross section of inelastic scattering of slow neutrons and the function $G(\varepsilon)$ is given by the following expression:

$$
\frac{d^{2} \sigma}{d \Omega d \varepsilon}=\frac{\hbar k Q^{2}}{8 \pi k_{0} \varepsilon} \frac{G_{s}(\varepsilon)}{\exp \left(\frac{\varepsilon}{k T}\right)-1},
$$

where $G(\varepsilon)=H_{s}(k, \varepsilon) \cdot g(\varepsilon)$;

$$
H_{s}(k, \varepsilon)=\sum_{i=1}^{n} C_{i} \frac{\sigma_{i}}{M_{i}} e^{-2 W_{i}}\left|\mathbf{e}_{i}(\varepsilon)\right|^{2} .
$$

Here, $n$ is the number of atoms in the unit cell; $\mathbf{k}_{0}$ and $\mathbf{k}_{i}$ wave vectors of falling and scattered neutrons; $\mathbf{Q}=\mathbf{k}_{0}-\mathbf{k}, \varepsilon$ is the change of impetus and energy in the process of scattering; $\sigma_{i}, M_{i}, C_{i}$ are the neutron scattering cross section, mass, and concentration of atoms of the $i$-th grade; $\left|\mathbf{e}_{i}(\varepsilon)\right|^{2}$ are the squares of the modules of the polarization vectors associated with the oscillations of the $i$-th atoms (averaging on the distribution of atoms on the nodes of the unit cell); $e^{-2 W_{i}}$ is the Debye-Waller factor.

In our experiments $G(\varepsilon)$ function was obtained from the following equation from spectra of inelastic scattered neutrons $N(t)$

$$
G_{\mathrm{S}}(\varepsilon)=\frac{8 \pi 10^{2} 4 k_{0} \varepsilon \hbar N(t) \Delta_{1}(t) \Delta_{2}(t)}{N_{0} n k Q^{2}} \exp \left(\frac{\varepsilon}{k T}\right)-1
$$

where $N_{0}$ is the amount of neutrons which fall on the sample; $n$ is the amount of sample nuclei on $1 \mathrm{~cm}^{2} ; \Delta_{1}(t)$, $\Delta_{2}(t)$ are the characteristics of the neutron spectrometer.

In the study of $\mathrm{ZrO}_{2}$-based solid solutions, the greatest attention was paid to the $\mathrm{ZrO}_{2}-\mathrm{Y}_{2} \mathrm{O}_{3}$ system, because it is associated with the largest amount of contradictory information regarding the ordering of structural elements in the crystal lattice. Particular attention has been paid to the research on the system $\mathrm{ZrO}_{2}-33 \%$ mol $\mathrm{Y}_{2} \mathrm{O}_{3}$, because in some papers, an assumption has been expressed about the formation of a pyrochlore type compound in it. Certainly, the presence of such structures in solid solutions based on $\mathrm{ZrO}_{2}$ stabilized by oxides of rare earth metals has been proved, but in the system $\mathrm{ZrO}_{2}-\mathrm{Y}_{2} \mathrm{O}_{3}$ these questions remain a topic of discussion. Our experiments assumed that the compounds having the same lattice and differing only by the atomic weight of additive components, must reveal the same oscillation spectra. Research to compare solid solutions $\mathrm{ZrO}_{2}-33 \%$ mol $\mathrm{Y}_{2} \mathrm{O}_{3}$ and $\mathrm{ZrO}_{2}-33 \% \mathrm{~mol}$
$\mathrm{Nd}_{2} \mathrm{O}_{3}$ has been carried out (the latter solution had a pyrochlore structure, according to the data obtained in some papers (from X-ray structure analysis). We have got the neutronograms (Fig. 1) of these compounds that, generally, do not having significant differences.

We obtained the X-ray diffractograms of these solid solutions too (Fig. 2 and Fig. 3). No significant differences were revealed, excepted of some pics intensity.
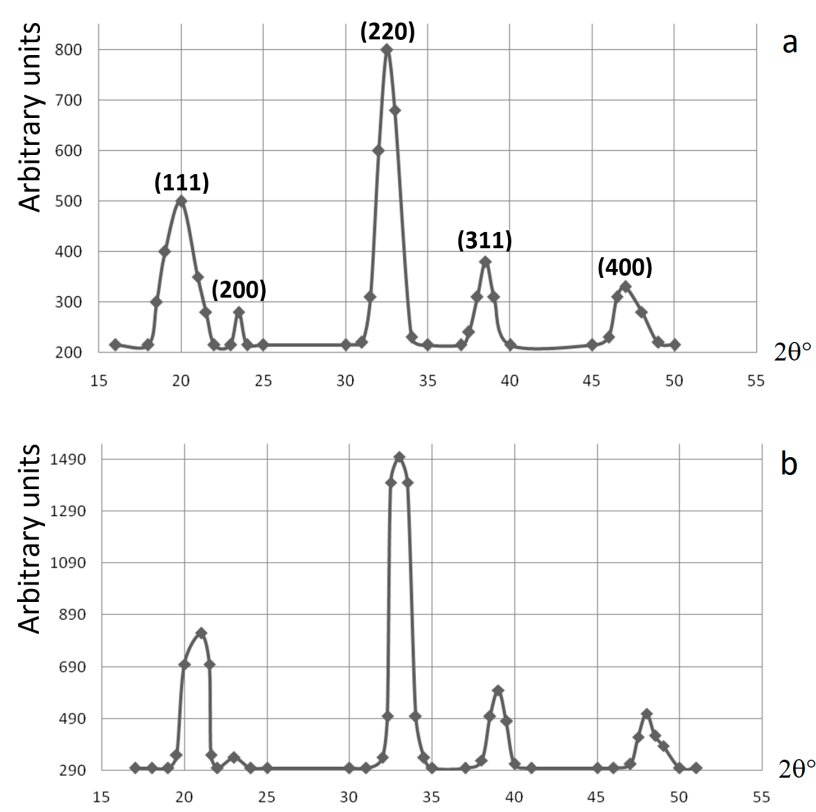

Fig. 1. Neutronograms of solid solutions based on zirconium dioxide: $\mathrm{a}-\mathrm{ZrO}_{2}-33 \%$ mol. $\mathrm{Y}_{2} \mathrm{O}_{3}, \mathrm{~b}-\mathrm{ZrO}_{2}-33 \%$ mol. $\mathrm{Nd}_{2} \mathrm{O}_{3}$

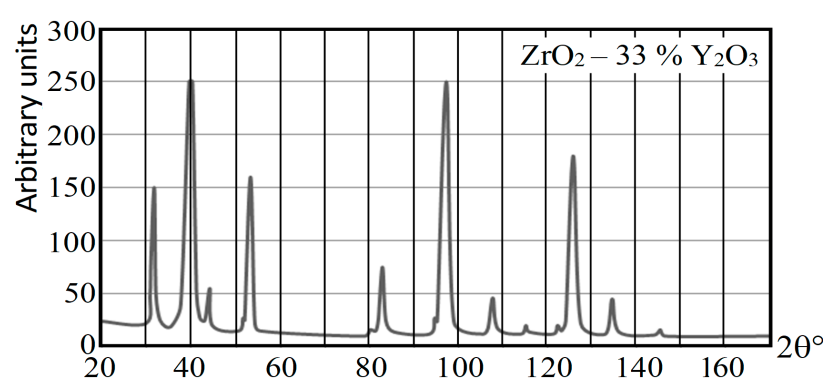

Fig. 2. X-ray diffractogram of zirconium dioxide with an addition $33 \% \mathrm{Y}_{2} \mathrm{O}_{3}$

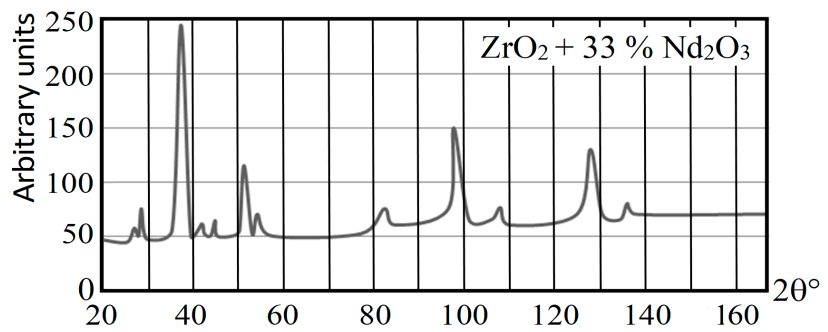

Fig. 3. X-ray diffractogram of zirconium dioxide with an addition of $33 \% \mathrm{Nd}_{2} \mathrm{O}_{3}$ 
Obviously, considering the results of our experiments, the conclusion about the existence or non- existence of such structure cannot be final. The spectra of both compounds are introduced in Figs. 4 and 5.

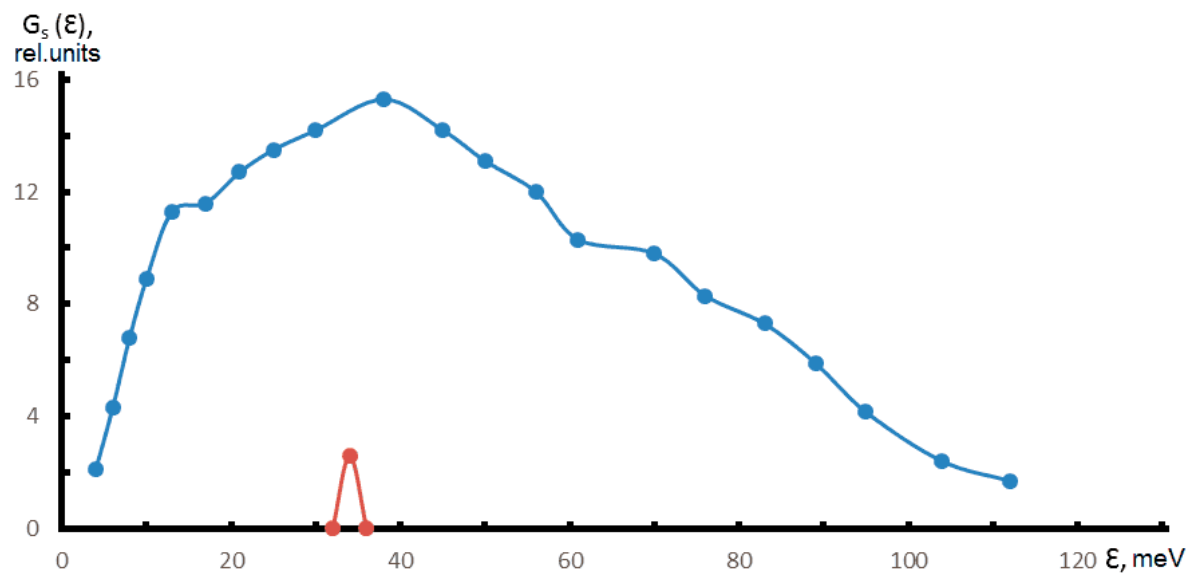

Fig. 4. View of function $G_{\mathrm{s}}(\varepsilon)$ for the solid solutions $\mathrm{ZrO}_{2}-33 \% \mathrm{~mol} \mathrm{Nd}_{2} \mathrm{O}_{3}$. The triangular shows the resolution of the $G_{\mathrm{s}}(\varepsilon)$ function determination

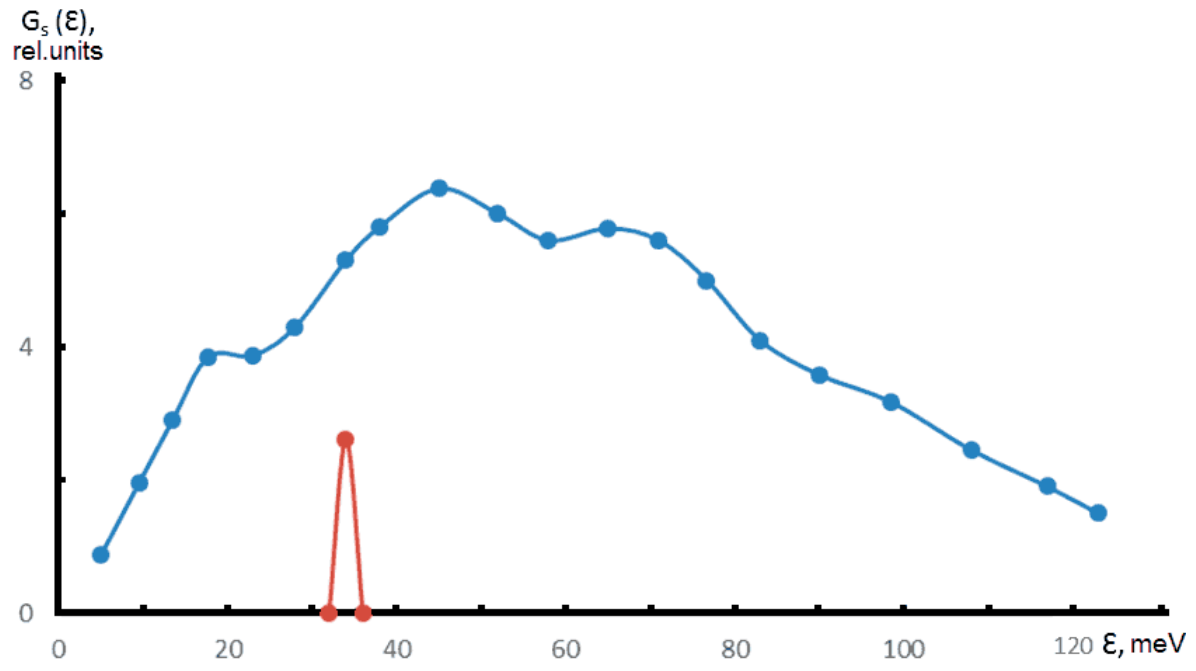

Fig. 5. View of function $G_{\mathrm{s}}(\varepsilon)$ for the solid solutions $\mathrm{ZrO}_{2}-33 \%$ mol $\mathrm{Y}_{2} \mathrm{O}_{3}$. The triangular shows the resolution of the $G_{\mathrm{s}}(\varepsilon)$ function determination

Analysis of the spectra leads to the conclusion that certain common features are present. There are maxima in the frequency density distribution in the range from 45 to $70 \mathrm{meV}$. However, in the case of $\mathrm{ZrO}_{2}-33 \% \mathrm{~mol}$ $\mathrm{Nd}_{2} \mathrm{O}_{3}$, the weight center of the spectrum is approximately $40 \mathrm{meV}$, while in the case of $\mathrm{ZrO}_{2}-33 \% \mathrm{~mol}$ $\mathrm{Y}_{2} \mathrm{O}_{3}$ it is located in the area of $60 \mathrm{meV}$. In our opinion, this can be caused mainly by a significant difference in the atomic weight of stabilizing ions, as well as a different grade of the structural elements order in the lattices of both systems.

Thus, our results, generally, are in accordance with the results of research [6], where the conclusion about a smooth transition between the structures of fluorite and a pyrochlore-type structure in system $\mathrm{ZrO}_{2}-\mathrm{Y}_{2} \mathrm{O}_{3}$ is made. The universal nature of the changes in the oscillation spectrum of pure zirconium dioxide atoms that take place with the introduction of stabilizing ions into the lattice matrix, is confirmed by the data from the research on system $\mathrm{ZrO}_{2}-15 \%$ mol $\mathrm{Sc}_{2} \mathrm{O}_{3}$ and $\mathrm{ZrO}_{2}$ - $20 \%$ mol CaO. There is an interesting point in the research of system $\mathrm{ZrO}_{2}-\mathrm{Sc}_{2} \mathrm{O}_{3}$. The ion of scandium $\left(\mathrm{Sc}^{3+}\right)$ is the only one ion that has as smaller size than the zirconium ion $\left(\mathrm{Zr}^{4+}\right)$ and nevertheless it stabilized a cubic phase [7]. This allows us to assume that the ordered location of the additive cation in the lattice of zirconium dioxide plays an important role in the cubic phase stabilization. Functions $G_{\mathrm{S}}(\varepsilon)$ for the above-mentioned systems are shown in Figs. 6 and 7 .

We can clearly observe a reduction in the density of normal oscillation in the energy range $55-60 \mathrm{meV}$. Neutronograms of these compounds generally are similar to the neutronograms described in other works, and differs only in relation "effect-background" for different structural reflections. There is an information [8] that in nanoparticles of the system $\mathrm{ZrO}_{2}-\mathrm{Y}_{2} \mathrm{O}_{3}$ subjected to annealing at $1250 \mathrm{~K}$ an ordered structure is formed, characterized by the dislocation of ion $\mathrm{O}_{2}-$ in flat (110) 
on average by $0.023 \mathrm{~nm}$ from positions corresponding to the fluorite-like solid solution. This ion dislocation is approximately $5 \%$ from the lattice parameter value for the stabilized solid solution $\mathrm{ZrO}_{2}$. Taking into account the fact that according to Lindeman rule, when thermal fluctuation increases to the value over $7 \%$ from lattice parameter this can lead to the crystal lattice melting. It is necessary to take a close look of the above mentioned effect as it can be linked to the significant changes in force constants inside the lattice. We have done a heat treatment to the two polycrystal samples to obtain an ordered as well as disordered structures. Both neutronograms and atom oscillation spectra did not have any difference for both samples. It must be emphasized that the experiments carried out by us were done using samples with an average size of the particles approximately $20.0 \mathrm{~nm}$ and were performed on monocrystals too. From this point of view, a possibility that this type of order may be obtained only in monocrystal systems cannot be excluded.

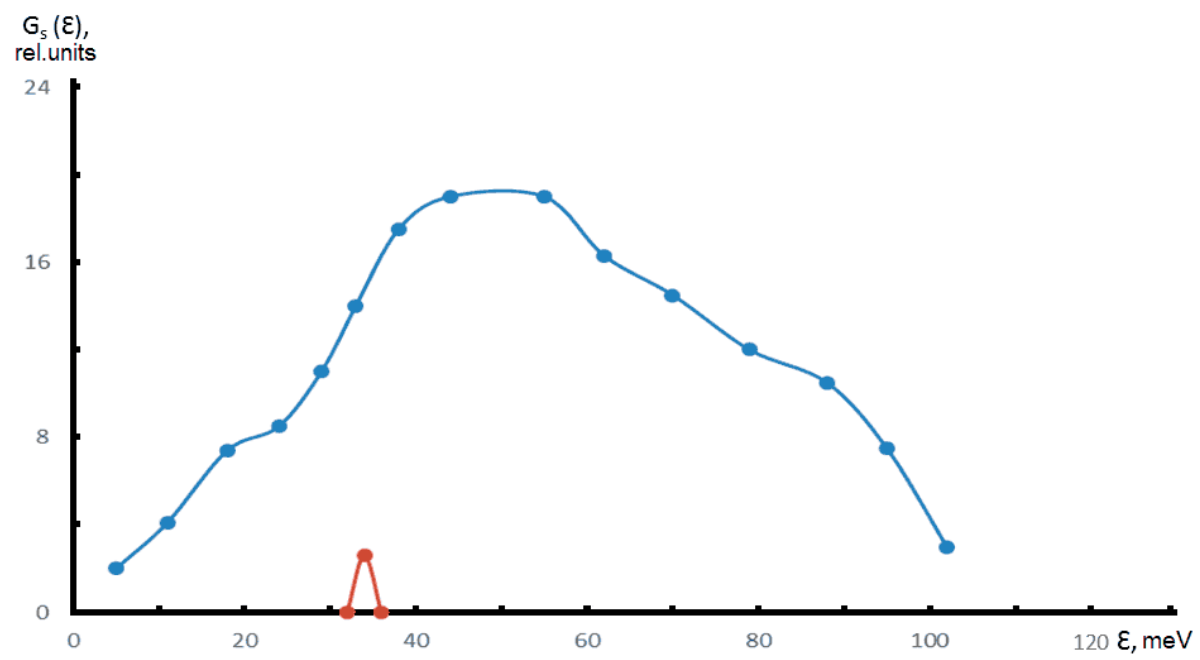

Fig. 6. View of function $G_{\mathrm{s}}(\varepsilon)$ for the solid solutions $\mathrm{ZrO}_{2}-33 \% \mathrm{CaO}_{2}$. The triangular shows the resolution of the $G_{\mathrm{s}}(\varepsilon)$ function determination

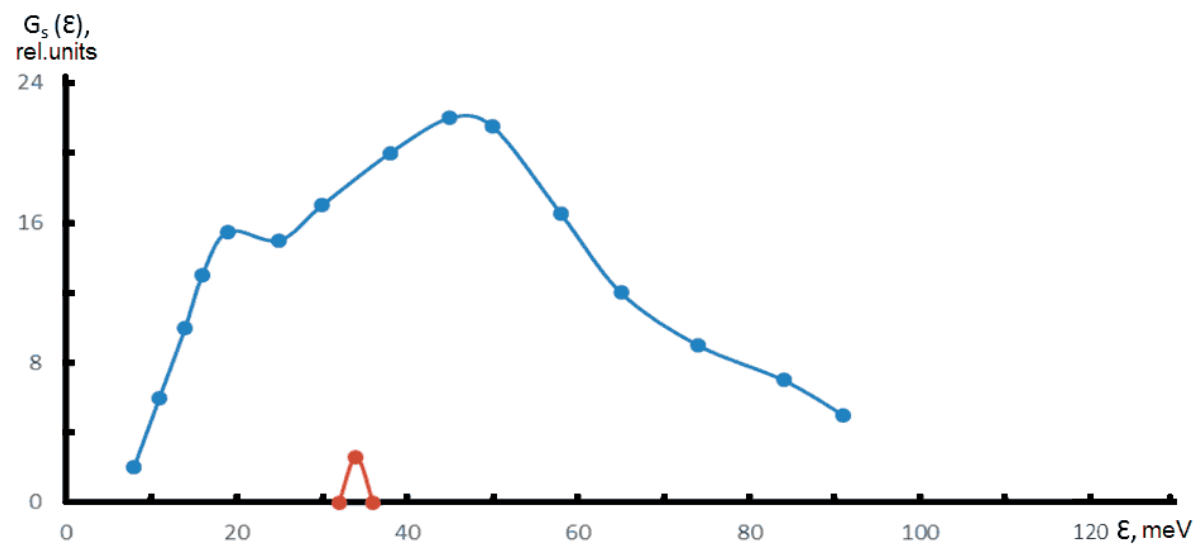

Fig. 7. View of function $G_{\mathrm{s}}(\varepsilon)$ for the solid solutions $\mathrm{ZrO}_{2}-15 \% \mathrm{Sc}_{2} \mathrm{O}_{3}$. The triangular shows the resolution of the $G_{\mathrm{s}}(\varepsilon)$ function determination

The "time-of-flight" method, which was used to carry out the research on atom oscillation spectra described above is integral and at present does not allow obtaining data about atom oscillations, whose energy corresponds to the narrow range of the spectrum. At the same time, it is necessary to know the frequency characteristics of separate fundamental oscillations when describing the mechanism of various phase transitions. That is why to determine particularity in atom oscillations of solid solutions based on $\mathrm{ZrO}_{2}$, we obtained ratios for high symmetricity directions (Fig. 8). The measurements have been carried out using KSN-2 in the "triple-axes spectrometer" mode, using monocrystals created using the method described in work [9]. It is known that solid solutions based on $\mathrm{ZrO}_{2}$ have FCC structure, that is why 9 branches must be observed in their spectra: 3 acoustical and 6 optical. We obtained dispersion ratios related only to the acoustical part of the spectrum which probably is linked to the high-level structure disorder in these crystals. 

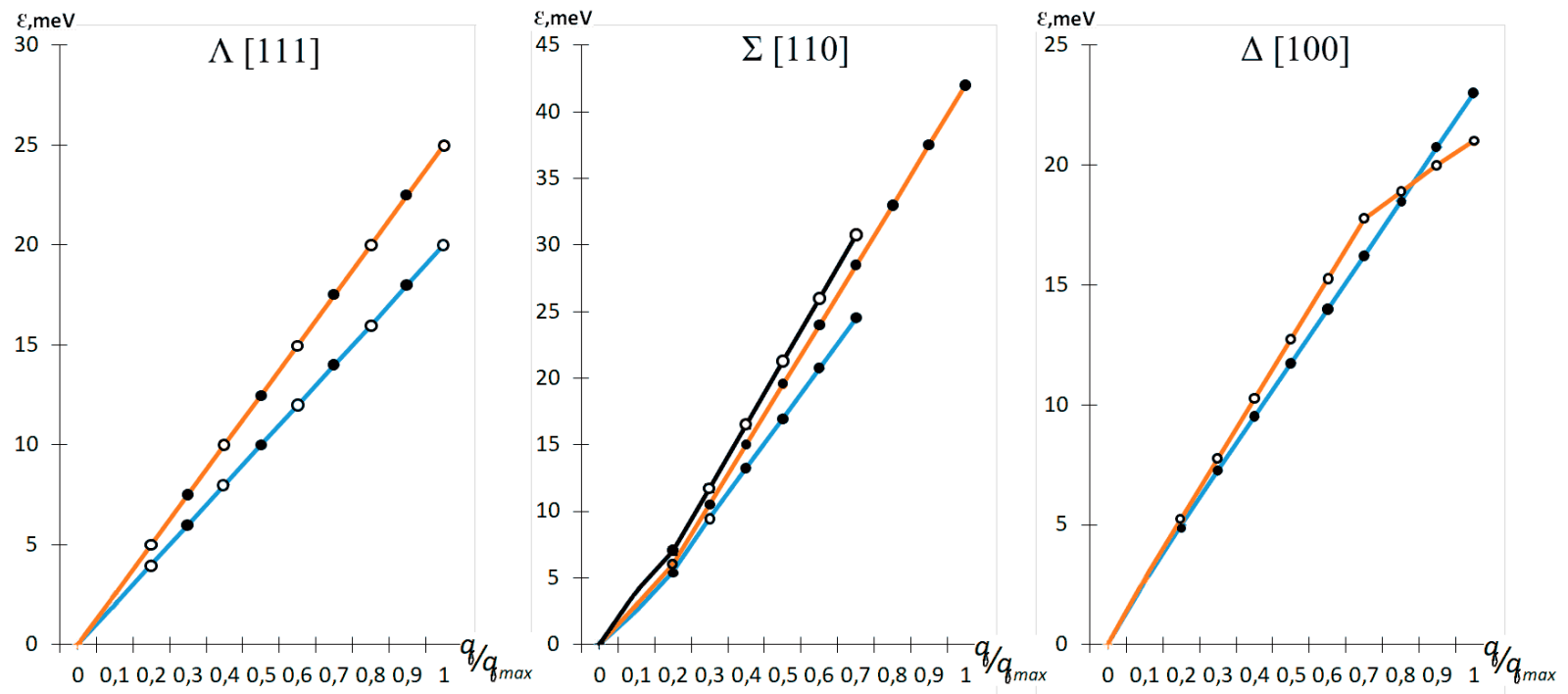

Fig. 8. The dispersion ratios in the system $(1-x) * \mathrm{ZrO}_{2}-x * \mathrm{Y}_{2} O_{3}, \circ-x=0.15, \bullet-x=0.1$

\section{CONCLUSION}

1. The obtained data of the lattice dynamics of solid solutions based on zirconium dioxide, when comparing with the data from work [6], allows assuming that with an increase in the stabilization ions concentration, specific heat capacity of these solid solutions will increase too.
2. The universal nature of changes in the oscillation spectrum of the zirconium dioxide crystal lattice has been confirmed during the introduction of different stabilization ions.

3. No evidence of a existence of pyrochlore type structure in $\mathrm{ZrO}_{2}-33 \%$ mol. $\mathrm{Y}_{2} \mathrm{O}_{3}$ was revealed.
[1] L. Smith, T. Mohammed, L. Koh, J. Reaney, J. Am. Ceram. Soc. 102, 703 (2019); https://doi.org/10.111 1/ jace. 16712.

[2] P. Platt, P. Frankel, M. Gass, R. Howels, M. Preuss, J. Nucl. Mater. 454, 290 (2014); https://doi.org/10.101 $6 /$ j.nucmat. 2014.08.020.

[3] G. Sharma, S. Ushakov, A. Navrotsky, J. Am. Ceram. Soc. 101, 31 (2018); https://doi.org/10.1111/jace.1 5200.

[4] O. Vasylkevytch et al., Ukr. J. Phys. 25, 381 (1980).

[5] V. Stubican, R. Hink, T. Ray, J. Am. Ceram. Soc. 61, 17 (1978); https://doi.org/10.1111/j.1151-2916.19 78. tb09220.x.
[6] Y. Moria, A. Navrotsky, J. Chem. Thermodyn. 38, 211 (2006); https://doi.org/10.1016/j.jct.2005.0 5.002.

[7] P. Simoncic, A. Navrotsky, J. Am. Ceram. Soc. 90, 2143 (2007); https://doi.org/10.1111/j.1551-2916. 2007.01678.x.

[8] C. Gaglieri, R. Alarcon, M. de Godoi, Thermochim. Acta 653, 59 (2017); https://doi.org/doi.org/10.1016/j. tca.2017.04.002.

[9] A. Sobol, U. Voronko, J. Phys. Chem. Solids 65, 1103 (2004); https://doi.org/10.1016/j.jpcs.2003.11.0 38.

\section{ДИНАМІКА КРИСТАЛІЧНОЇ ГРАТКИ ТВЕРДИХ РОЗЧИНІВ НА ОСНОВІ ДІОКСИДУ ЦИРКОНІЮ}

В. І. Слісенко ${ }^{1}$, О. Є. Зотєєв ${ }^{2}$, О. О. Василькевич ${ }^{1}$, В. О. Зотєєв ${ }^{2}$, В. В. Кротенко ${ }^{1}$

${ }^{1}$ Інститут ядерних дослідженъ НАН Украӥни, просп. Науки, 47, Киӥв, 03028, Украӥна,

${ }^{2}$ Одесъкий начіоналъний політехнічний університет, просп. Шевченка, 1, Одеса, 65044, Украӥна

Тверді розчини на базі діоксиду цирконію широко використовують у техніці внаслідок їхніх унікальних властивостей. Діоксид цирконію має моноклінну структуру, але під впливом тиску, температури та радіаційного навантаження може трансформуватися в тетрагональну форму. Цей перехід супроводжується зменшенням питомого об'єму майже на 10-15\%. Особливу увагу привертає цей 
факт під час розгляду формування тонкої плівки діоксиду цирконію на поверхні оболонки твелів у процесі експлуатації тепловидільних касет у ядерному реакторі. Фазовий перехід у плівці діоксиду цирконію може призвести до пошкоджень оболонки твелів та витоку радіоактивних ізотопів у теплоносій першого контуру реактора. Такий витік може спричинити зупинку експлуатації ядерного блоку. Водночас відомо, що введення рідкоземельних оксидів у тверді розчини на базі діоксиду цирконію стабілізує кубічну структуру цих систем, яка не змінюється під час опромінення. У роботі досліджено структури та динаміки кристалічної гратки твердих розчинів на базі діоксиду цирконію. Структурні експерименти проведено на нейтронному спектрометрі KSN-2 в режимах "дифрактометр" та "тривісний спектрометр", а також рентгенівському дифрактометрі ДРОН-3.0 (лінія $\mathrm{Fe} K \alpha$ $\lambda=0.194$ нм). Фононні спектри твердих розчинів отримано методом непружного розсіювання теплових нейтронів. Дисперсійні співвідношення одержано на монокристалічних зразках. Відомо, що введення в кристалічну гратку $\mathrm{ZrO}_{2}$ таких йонів, як $\mathrm{Ca}, \mathrm{Y}, \mathrm{Nd}, \mathrm{Sc}$, стабілізує кубічну структуру гратки. Особливу увагу приділено системі $\mathrm{ZrO}_{2}-33 \%$ моль $\mathrm{Y}_{2} \mathrm{O}_{3}$. У ній розглянуто можливість виникнення структури типу пірохлору. Під час експериментів установлено, що зміни в спектрі коливань кристалічної гратки твердих розчинів на базі діоксиду цирконію з різними йонами-стабілізаторами мають універсальний характер. Отримані результати, порівняно з іншими дослідженнями цих систем, дозволяють припустити, що зі зростанням концентрації йонів-стабілізаторів зростає й питома теплоємність твердих розчинів.

Ключові слова: динаміка кристалічної гратки, непружне розсіювання, теплові нейтрони. 